\title{
ANALISIS YURIDIS TERHADAP LAPORAN AKUNTABILITAS KINERJA INSTANSI PEMERINTAH DAERAH TAHUN 2013 PADA \\ DINAS PENDIDIKAN PROVINSI JAWA TENGAH SEBAGAI IMPLEMENTASI PELAKSANAAN OTONOMI DAERAH
}

\author{
Yudhitiya Dyah Sukmadewi ${ }^{1}$, Retno Saraswati ${ }^{2}$
}

\begin{abstract}
Abstrak
Penelitian ini bertujuan mengkaji apakah Laporan Akuntabilitas Kinerja Instansi Pemerintah Daerah Tahun 2013 pada Dinas Pendidikan Provinsi Jawa Tengah sudah sesuai dengan UU No.32 Tahun 2004 Tentang Otonomi Daerah, dan hambatan-hambatan yang dihadapi dalam pelaksanaannya. Metode pendekatan yang digunakan dalam penelitian ini adalah yuridis normatif dengan menggunakan data sekunder berupa peraturan perundang-undangan dan bahan kepustakaan lainnya. Hasil penelitian menunjukkan bahwa pelaksanaan otonomi daerah di bidang pendidikan pada tahun 2013, oleh Dinas Pendidikan Provinsi Jawa Tengah telah sesuai dengan amanat UU No.32 Tahun 2004, namun masih terdapat beberapa program kerja yang belum dapat memenuhi indikator kinerja. Yang menjadi hambatan, meliputi: rendahnya tingkat kesadaran masyarakat pentingnya pendidikan; masih terbatasnya sarana dan prasarana; persebaran tenaga kependidikan yang berkualitas dan berkompeten, serta pengembangan kurikulum dan metode pembelajaran yang belum merata sehingga Dinas Pendidikan harus lebih aktif lagi melakukan sosialisasi untuk menumbuhkan kesadaran pentingnya pendidikan, dan menyediakan sarana prasarana.
\end{abstract}

Kata Kunci: Laporan Akuntabilitas Kinerja Instansi Pemerintah Daerah Tahun 2013, Dinas Pendidikan Provinsi Jawa Tengah, Otonomi Daerah

\section{A. Latar Belakang}

Seluruh masyarakat berhak dan wajib memperoleh pendidikan yang layak, memadai dan berkualitas sebagaimana diamanatkan dalam tujuan negara dan UUD 1945, oleh karena itu, negara wajib menjamin ketersediaan pelayanan pendidikan yang layak dan berkualitas bagi rakyatnya tanpa adanya diskriminasi. Urusan pendidikan dapat

\footnotetext{
${ }^{1}$ Mahasiswa Program Studi Magister IImu Hukum UNDIP

${ }^{2}$ Dosen Program Studi Magister Ilmu Hukum UNDIP
} 
diserahkan oleh pemerintah pusat kepada pemerintah daerah untuk mengaturnya sendiri dengan prinsip otonomi daerah. Dalam kerangka otonomi daerah, pemenuhan pelayanan pendidikan membutuhkan keterpaduan dan keselarasan kebijakan, program maupun kegiatan pembangunan pendidikan antara pemerintah, pemerintah provinsi dan pemerintah kabupaten/kota. Pelaksanaan otonomi daerah dilaksanakan berdasarkan Undang-Undang No. 32 Tahun 2004 Tentang Pemerintahan Daerah (selanjutnya disebut UU No. 32 Tahun 2004).

Melalui Dinas Pendidikan Provinsi Jawa tengah, selaku dinas daerah yang merupakan unsur pelaksana otonomi daerah dibidang pendidikan, Penulis tertarik untuk mengetahui dan mengkaji apakah Provinsi Jawa Tengah melalui Dinas Pendidikannya, sudah dapat melaksanakan otonomi daerah di bidang pendidikan dengan baik atau justru sebaliknya. Pelaksanaan otonomi daerah oleh Dinas Pendidikan Provinsi Daerah nantinya akan dikaji berdasarkan Laporan Akuntabilitas Kinerja Instansi Pemerintah Daerah Tahun 2013. Kemudian, juga dikaji mengenai hambatan yang dihadapi Dinas Pendidikan Provinsi Jawa Tengah dalam melaksanakan otonomi daerah bidang pendidikan tersebut.

\section{B. Metode Penelitian}

Metode pendekatan yang digunakan dalam penelitian ini adalah metode pendekatan yuridis normatif, yaitu suatu penelitian yang berusaha mensinkronisasikan ketentuan hukum yang berlaku dengan kaedah-kaedah dalam pengawasan hukum, terhadap normanorma atau peraturan-peraturan hukum lainnya, dengan kaitannya dalam penerapan peraturan-peraturan hukum itu pada praktek nyatanya di lapangan. ${ }^{3}$. Penelitian ini menggunakan data sekunder yang dilengkapi pula dengan data-data lapangan sebagai data pendukung. Kemudian, data tersebut diolah dan dianalisis secara kualitatif.

\section{Hasil dan Pembahasan}

3 Burhan Ashofa, 2001, Metode Penelitian Hukum, Jakarta: Rineka Cipta, hlm. 25 


\section{Analisis Yuridis Laporan Akuntabilitas Kinerja Instansi Pemerintah Daerah (LAKIP Daerah) Tahun 2013 pada Dinas Pendidikan Provinsi Jawa Tengah Berdasarkan UU No. 32 Tahun 2004 Tentang Pemerintahan Daerah.}

Dinas Pendidikan Provinsi Jawa Tengah telah menetapkan 9 program utama yang dilaksanakan pada tahun 2013 sebagaimana tercantum dalam perencanaan kinerja. Klasifikasi program pembangunan pendidikan di Jawa Tengah disusun berdasarkan jenjang pendidikan, ketenagaan kependidikan, manajemen pelayanan pendidikan dan pendidikan berkelanjutan serta program pendukung. Adapun keseluruhan program tersebut meliputi Program Pendidikan Anak Usia Dini (PAUD); Program Pendidikan Dasar (Dikdas); Program Pendidikan Menengah (Dikmen); Program Pendidikan Non Formal dan Informal (PNFI); Program Pengembangan Pendidik dan Tenaga Kependidikan; Program Pendidikan Khusus (Diksus); Program Fasilitasi Perguruan Tinggi; Program Manajemen Pelayanan Pendidikan; Program Pendidikan Berkelanjutan. Berdasarkan program kerja dan capaian kinerja Dinas Pendidikan Provinsi Jawa Tengah Tahun 2013, menunjukkan bahwa jangkauan pelayanan pendidikan telah mencakup seluruh lapisan masyarakat, mulai dari usia dini hingga usia lanjut, dan mulai masyarakat normal hingga masyarakat berkebutuhan khusus. Semuanya dapat terfasilitasi dengan adanya program-program yang telah diselenggarakan selama tahun 2013, meskipun ada beberapa kegiatan dari masing-masing program yang belum dapat terealisasi sesuai dengan target. Pada dasarnya, penyelenggaraan urusan pendidikan di Jawa tengah telah dapat dijalankan oleh Dinas Pendidikan, namun capaiannya belum optimal.

Dari 9 (sembilan) program utama yang terlaksana, 5 (lima) program masih terdapat kegiatan yang belum dapat memenuhi target, sedangkan 4 (empat) program seluruh kegiatannya telah dapat memenuhi target. Adapun program-program yang belum dapat memenuhi target secara keseluruhan adalah program pendidikan dasar, 
program pendidikan menengah, program pendidikan non formal, program peningkatan mutu pendidikan dan tenaga kependidikan, serta program manajemen pelayanan pendidikan, sedangkan program dengan kegiatan yang belum memenuhi target paling banyak, adalah program pendidikan non-formal dan program peningkatan mutu pendidikan dan tenaga kependidikan. Di sisi lain, peningkatan layanan pendidikan di Jawa Tengah pada tahun 2013, terwujud dengan terealisasinya kegiatan-kegiatan sebagai berikut :

a. Terealisasinya wajib belajar 9 tahun bagi masyarakat Jawa Tengah, karena wajib belajar 9 tahun merupakan pendidikan paling dasar yang wajib dimiliki oleh setiap anak didik.

b. Peningkatan antusiasme masyarakat Jawa Tengah untuk meneruskan pendidikannya ke tingkat pendidikan menengah baik pada tingkat SMA maupun SMK

c. Peningkatan pelayanan pendidikan, terealisasi dengan adanya pendidikan dan pembinaan bagi peserta didik yang berkebutuhan khusus sehingga yang bersangkutan dapat memperoleh pendidikan yang memadai layaknya peserta didik dengan kondisi normal, dan dapat memperoleh terapi psikologi maupun terapi fisik yang sangat membantu.

d. Peningkatan pelayanan pendidikan terealisasi dengan adanya pendidikan non formal, sehingga masyarakat dapat memperoleh kesetaraan pendidikan seperti pada pendidikan formal, dan dapat memperoleh keahlian-keahlian khusus yang diperoleh melalui lembaga-lembaga kursus, meskipun tingkat capainnya belum seluruhnya dapat memenuhi target.

e. Peningkatan terealisasi dengan adanya peningkatan mutu kependidikan dan tenaga pendidik melalui kualifikasi pendidikan yang diprioritaskan minimal 
Sarjana dan dengan adanya fasilitasi sertifikasi profesi tenaga pendidikan guna mendukung kualitas para tenaga pendidik.

f. Peningkatan layanan pendidikan terealisasi dengan adanya manajemen pelayanan pendidikan yang modern dengan terwujudnya pelayanan pendidikan yang sistematis, terpadu dan mudah dalam pengaksesannya melalui sistem online. Selain itu, terwujud pula prestasi akademik maupun non akademik oleh siswa-siswi di Jawa Tengah yang memperoleh medali pada kejuaraan tingkat nasional maupun internasional, serta dilakukannya kerjasama Dinas Pendidikan provinsi Jawa Tengah dengan negara-negara lain, khususnya mengenai urusan pendidikan.

g. Peningkatan layanan pendidikan terealisasi dengan adanya fasilitasi perguruan tinggi, dimana terdapat kerjasama antara perguruan tinggi di jawa tengah dengan Dinas Pendidikan Provinsi jawa Tengah mengenai urusan pendidikan.

h. Peningkatan layanan pendidikan terealisasi dengan adanya pendidikan berkelanjutan yang mewujudkan peserta didik dengan pendidikan karakter dan tindakan-tindakan sosial, yang salah satunya berupa penyelenggaraan simulasi penanganan terhadap bencana.

Unsur pemberdayaan dan peran serta masyarakat terwujud dengan adanya antusiasme masyarakat Jawa Tengah dalam melaksanakan pendidikan dari tingkat dini hingga tingkat yang lebih tinggi, dan ikut mendukung dan berpartisipasi dalam pelaksaan setiap program yang dilaksanakan oleh Dinas Pendidikan provinsi jawa Tengah.

Berdasarkan capaian kinerja dalam Lakip daerah ini, Penulis mengkaji bahwa Pemerintah Daerah Provinsi Jawa Tengah telah melaksanakan amanat otonomi daerah sebagaimana diatur dalam UU No.32 tahun 2004. Adapun ketersesuaian tersebut meliputi pengkajian pada makna otonomi daerah Pasal 1 angka 5; Tujuan otonomi 
daerah berdasarkan penjelasan UU No.32 tahun 2004; Prinsip otonomi daerah yang meliputi prinsip otonomi luas, nyata dan bertanggungjawab; Asas penyelenggaraan otonomi daerah berdasarkan Pasal 20 ayat 1 dan ayat 3 UU No.32 tahun 2004; Kewajiban daerah berdasarkan Pasal 22.

Selain pengkajian otonomi daerah pada Dinas Pendidikan Provinsi Jawa Tengah tahun 2013 berdasarkan UU No.32 Tahun 2004, Penulis juga akan mengkaji pelaksanaan otonomi daerah tersebut berdasarkan PP No.38 Tahun 2007 Tentang Pembagian Urusan Pemerintahan antara Pemerintah, Pemerintahan Daerah Provinsi dan Pemerintahan Daerah Kabupaten/Kota. Dalam PP No.38 Tahun 2007 disebutkan bahwa pembagian urusan pemerintahan di bidang pendidikan, yang menjadi kewenangan pemerintahan daerah provinsi meliputi 6 sub bidang, yaitu kebijakan, pembiayaan, kurikulum, sarana dan prasarana, pendidik dan tenaga kependidikan, serta sub bidang pengendalian mutu pendidikan. Berdasarkan pengkajian, dinyaakan bahwa pelaksanaan otonomi daerah di bidang pendidikan pada tahun 2013, oleh Dinas Pendidikan provinsi Jawa Tengah berdasarkan PP No.38 Tahun 2007 telah sesuai dengan kewenangan penyelenggaraan urusan pemerintahan provinsi yang dijabarkan dalam PP No.38 Tahun 2007.

\section{Hambatan dan Upaya Penanganan Hambatan Terhadap Penyelenggaraan} Urusan Pendidikan di Jawa tengah Tahun 2013 Oleh Dinas Pendidikan provinsi Jawa Tengah.

Hambatan-hambatan yang ditemui oleh Dinas Pendidikan provinsi Jawa Tengah dalam pelaksanaan program kerja pada tahun 2013, yaitu:

a. Program PAUD : Jumlah anak yang belum mengikuti PAUD masih cukup banyak, khususnya pada rentang usia 0-2 tahun; Sarana dan prasarana masih terbatas; kreativitas metode pembelajaran masih terbatas; Kompetensi tenaga pengajar PAUD masih rendah karena tidak berasal dari latar belakang pendidikan 
PAUD; kesenjangan angka partisipasi PAUD di perkotaan dan pedesaan masih sangat besar. Sebagai langkah untuk mengatasi hambatan-hambatan tersebut, pada tahun anggaran selanjutnya harus dilakukan upaya-upaya Fokus pelayanan PAUD terhadap anak usia 3-6 tahun;.Peningkatan fasilitasi pemenuhan sarana prasarana PAUD layak dan pengembangan metode pembelajaran PAUD; Peningkatan pelatihan guru PAUD yang terstruktur dan pendampingan guru PAUD prestasi dalam pembelajaran di PAUD sekitarnya; Pemenuhan pembentukan seribu POS PAUD di Jawa Tengah.

b. Program pendidikan dasar (dikdas): Masih adanya anak usia SD/MI/SDLB yang tidak sekolah karena bekerja membantu orang tua dengan alasan keterbatasan ekonom; kemudian masih rendahnya kesadaran akan pentingnya mendapatkan pendidikan. Adapun upaya yang dilakukan untuk mengatasi hambatan tersebut adalah dilakukan program sosialisasi penanaman kesadaran pendidikan di semua kalangan, khususnya pada kalangan masyarakat tidak mampu sekaligus dilakukan sosialisasi mengenai beasiswa untuk pendidikan khususnya program wajib belajar 9 tahun yang dibiayai oleh pemerintah.

c. Program pendidikan menengah (dikmen) : Masih banyak dijumpai anak lulusan SMP/MTs yang tidak melanjutkan ke tingkat pendidikan menengah (SMA atau SMK) karena bekerja membantu orang tua. Upaya pertama yang harus dilakukan oleh Dinas Pendidikan Provinsi Jawa Tengah adalah peningkatan fasilitasi sarana dan prasarana sekolah SMA maupun SMK, khususnya pada daerah-daerah terpencil yang sulit dijangkau dengan transportasi; Selanjutnya, dilakukan sosialisasi kepada masyarakat mengenai pentingnya peran pendidikan untuk menjamin masa depan yang lebih baik. Sosialisasi tersebut juga dipadukan dengan arahan untuk pemilihan SMA maupun SMK yang disesuaikan dengan kebutuhan masing-masing peserta didik. 
d. Program pendidikan non-formal dan informal (PNFI) : tidak tercapainya angka kelulusan pendidikan kesetaraan kejar paket A, paket B maupun paket C. Hal ini antara lain disebabkan karena belum semua warga belajar pendidikan kesetaraan, memiliki kesadaran untuk menyelesaikan pendidikannya dan mengikuti ujian sesuai jadwal yang telah ditetapkan. Artinya, antusiasme dalam menyelesaikan pendidikan kesetaraan tersebut masih rendah. Dalam mengatasi permasalahan, upaya yang dilakukan adalah koordinasi dengan lembaga-lembaga penyelenggara pendidikan kesetaraan, untuk mengadakan pembenahan metode pembelajaran; Selain itu rekrutmen pengajar diarahkan pada tenaga pendidik yang tidak hanya mampu memberikan pembelajaran, namun juga mampu memberikan motivasi untuk mengikuti pembelajaran kesetaraan; pembenahan manajemen pendidikan.

e. Program pendidikan khusus (diksus) : seluruh kegiatannya memenuhi target indikator kinerja, namun perlu ditingkatkan dan diberdayakan lebih banyak lagi mengenai layanan pendidikan khusus pada Balai Pengembangan Pendidikan Khusus yang diarahkan guna membantu anak berkebutuhan khusus untuk mendapatkan layanan yang memadai dan terjangkau dalam bentuk pemberian layanan terapi dan psikologi bagi anak berkebutuhan khusus.

f. Penyelenggaraan program peningkatan mutu pendidik dan tenaga kependidikan (PMPTK) : masih sedikitnya jumlah tenaga pendidik yang memiliki kualifikasi pendidikan Sarjana, dan terbatasnya kuota sertifikasi profesi dari Pemerintah pusat. Upaya-upaya yang harus dilakukan dalam mengatasi permasalahan tersebut adalah yang pertama, harus dilakukan peningkatan pelatihan tenaga pendidik yang terstruktur dan pendampingan tenaga pendidik yang berprestasi dalam pembelajaran di masing-masing jenjang pendidikan; Adanya pendampingan tenaga pendidik bagi pendidik-pendidik yang berprestasi, terutama pada daerahdaerah pelosok harus ditindaklanjuti dengan bentuk pemberian beasiswa bagi 
tenaga pendidik yang berprestasi; koordinasi dengan pemerintah daerah Kabupaten/Kota di wilayah Jawa Tengah mengenai sistem perekrutan CPNS Daerah untuk tenaga kependidikan yang disesuaikan dengan kuota dan penempatan; koordinasi antara Pemerintah Provinsi Jawa Tengah dengan Pemerintah pusat mengenai kuota baku dalam sertifikasi profesi tenaga pendidik, serta permohonan untuk kuota sertifikasi tambahan.

g. Penyelenggaraan program fasilitasi perguruan tinggi : tidak ditemui hambatan dalam pelaksanaannya, namun harus dilakukan peningkatan kerjasama antara pemerintah daerah dengan perguruan tinggi yang berada di Jawa tengah, salah satunya dalam rangka perumusan kebijakan daerah untuk pembangunan daerah yang lebih baik lagi kedepannya, peningkatan pengabdian masyarakat oleh perguruan tinggi di Jawa tengah; Fasilitasi beasiswa dari Pemerintah provinsi Jawa Tengah kepada mahasiswa-mahasiswa kurang mampu pada perguruan tinggi di Jawa tengah.

h. Program manajemen pelayanan pendidikan : rendahnya penguatan perencanaan pendidikan yang transparan, visioner dan adaptif terhadap lingkungan strategis pendidikan; perbaikan manajemen kinerja pembangunan pendidikan Jawa Tengah. Adapun upaya-upaya untuk mengatasi permasalahan tersebut adalah mulai dilakukan perencanaan program sebagai fasilitasi penguatan perencanaan pendidikan yang dapat dimasukkan dalam draft Renstra Dinas Pendidikan Jawa Tengah pada tahun 2013-2018; dilakukan upaya peningkatan evaluasi dan pengendalian program kegiatan secara berkala dengan lebih seksama lagi. Salah satu hasil evaluasi tersebut termasuk penyusunan Lakip Dinas Pendidikan Provinsi Jawa Tengah; Sistem pendataan melalui biosystem, harus disinergikan dengan sosialisasi lebih lanjut untuk memberikan pemahaman mengenai 
pendataan data pendidikan secara online tersebut; dan harus dilakukan pula pengelolaan manajemen data pendidikan.

i. Program pendidikan berkelanjutan : mayoritas pelaksanaan kegiatan-kegiatan dilakukan dengan baik dan maksimal, namun diperlukan upaya-upaya untuk meningkatkan kinerja program agar lebih baik lagi kedepannya, meliputi dilakukannya peningkatan pendidikan karakter (penyelenggaraan jamboree nasional) dengan dilakukan pengembangan dan inovasi terhadap muatan kegiatan agar berbeda tiap tahunnya; dilakukan peningkatan perluasan kerjasama sekolah dengan instansi-instansi tertentu guna pemberian bekal keterampilan tertentu maupun tambahan informasi yang berkaitan dengan pendidikan, misal PMI, BNN,BPOM, dan lain sebagainya.

\section{Simpulan}

Pelaksanaan otonomi daerah di bidang pendidikan pada tahun 2013, oleh Dinas Pendidikan Provinsi Jawa Tengah telah sesuai dengan amanat UU No.32 Tahun 2004 dan PP No.38 tahun 2007. Meskipun pelaksanaannya telah sesuai, namun masih terdapat beberapa program kerja yang belum dapat memenuhi indikator kinerja. Keseluruhan hambatan-hambatan yang ditemui dalam penyelenggaraan program kerja tahun 2013 pada dasarnya meliputi, rendahnya tingkat kesadaran masyarakat akan pentingnya kebutuhan pendidikan, terutama pada masyarakat ekonomi tingkat bawah; masih terbatasnya sarana dan prasarana pendidikan yang layak untuk mendukung kegiatan belajar mengajar; persebaran tenaga kependidikan yang berkualitas dan berkompeten kurang merata; pengembangan dan peningkatan kurikulum dan metode pembelajaran yang belum merata.

Adapun upaya-upaya yang harus dilakukan dalam mengatasi hambatan tersebut adalah pertama, Dinas Pendidikan Provinsi Jawa Tengah harus lebih aktif lagi melakukan sosialisasi untuk menumbuhkan kesadaran pentingnya pendidikan. Kedua, harus 
dilakukan review kembali mengenai ketersediaan sarana dan prasarana dengan jumlah satuan pendidikan yang ada. Ketiga, Dinas Pendidikan Provinsi Jawa Tengah harus lebih selektif dalam menempatkan tenaga pendidik pada satuan pendidikan di wilayah Jawa Tengah. Keempat, sosialisasi dan pendampingan mengenai pembaharuan kurikulum harus dilaksanakan secara rutin dan berkala.

\section{Daftar Pustaka}

Ashofa, Burhan, 2001, Metode Penelitian Hukum, Jakarta: Rineka Cipta 